\title{
Thermal induction of heat shock proteins Hsp70 and Hsp90 in tissues of the nemerteans Lineus alborostratus Takakura, 1898 and Quasitetrastemma stimpsoni (Chernyshev, 1992)
}

\author{
A.V. Chernyshev ${ }^{1,2}$, E.P. Kotsyuba ${ }^{1}$, R.K. Okazaki ${ }^{3}$ \\ ${ }^{1}$ A.V. Zhirmunsky Institute of Marine Biology, National Scientific Center of Marine Biology Far \\ East Branch, Russian Academy of Sciences, Vladivostok 690041 Russia. E-mail: \\ nemertea1969@gmail.com \\ ${ }^{2}$ Far Eastern Federal University, Vladivostok 690600 Russia. \\ ${ }^{3}$ Department of Zoology, Weber State University, 1415 Edvalson Street, Dept. 2505, Ogden, UT \\ 84408-2505, USA.
}

\begin{abstract}
Intertidal ribbon worms in the phylum Nemertea live in environments where temperature and salinity can vary widely depending on the tidal fluctuations. Heat shock proteins (Hsps) are expressed by cells in their physiological responses to these changing abiotic factors. To understand the role of Hsps, the presence of Hsp70 and Hsp90 was determined by western blotting in two nemertean species, Lineus alborostratus and Quasitetrastemma stimpsoni after 2- and 4-h thermal stress. Additionally, their tissue distributions of these Hsps were detected by immunohistochemistry. Both Hsps were detected in the two nemertean species. In L. alborostratus, Hsp70 and Hsp90 immunoreactivities were detected in the body wall, specifically in the epidermal and cutis cells, as well as in the epithelia of the stomach and proboscis; Hsp immunoreactivities in these cells and tissues appeared higher in the thermally-stressed nemerteans compared to the controls. For both the control and thermally-stressed Q. stimpsoni, Hsp70 and Hsp90 were localized in the epidermis, while the stomach epithelium and neurons of the lateral nerve cord showed low immunoreactivities in the thermally-stressed worms. In thermally-stressed L. alborostratus, the proboscis showed a marked increase of Hsp70 and Hsp90 immunoreactivity. Active immunoreactivities were observed in the supra-epidermal granules in both ribbonworm species, especially Q. stimpsoni. Accumulation of Hsp70 and Hsp90 in the body wall and the gastric epithelium of nemerteans may indicate their importance during their physiological response to thermal stress.

How to cite this article: Chernyshev A.V., Kotsyuba E.P., Okazaki R.K. 2018. Thermal induction of heat shock proteins Hsp70 and Hsp90 in tissues of the nemerteans Lineus alborostratus Takakura, 1898 and Quasitetrastemma stimpsoni (Chernyshev, 1992) // Invert. Zool. Vol.15. No.1. P.51-70. doi: 10.15298/invertzool.15.1.04
\end{abstract}

KEY WORDS: Hsp70, Hsp90, thermal stress, nemerteans, immunohistochemistry.

\section{Термическая индукция белков теплового шока Нsp70 и Hsp90 у немертин Lineus alborostratus Takakura, 1898 и Quasitetrastemma stimpsoni (Chernyshev, 1992)}

А.В. Чернышев ${ }^{1,2}$, Е.П. Коцюба' ${ }^{1}$ Р.К. Оказаки ${ }^{3}$

\footnotetext{
${ }^{1}$ Институт биологии моря им. А.В. Жирмунского, Наџиональный научный иентр морской биологии ДВО РАН, Владивосток 690041 Россия. E-mail: nemertea1969@gmail.com 2 Дальневосточный федеральный университет, Владивосток 690950 Россия.
} 
${ }_{3}$ Отделение Зоологии, Вебер государственный университет, 1415 Edvalson Street, Dept. 2505, Орден, Юта 84408-2505, США.

РЕЗЮМЕ: Литоральные немертины живут в условиях, где температура и соленость может изменяться в широких пределах в зависимости от приливных колебаний. Экспрессия белков теплового шока (Hsp) является физиологической реакцией в ответ на эти изменяющиеся абиотические факторы среды. Для понимания их роли HSPs в адаптации методами вестерн-блоттинга и иммуногистохимии изучали наличие и распределение Нsp70 и Нsp90 у двух видов немертин, Lineus alborostratus и Quasitetrastemma stimpsoni после 2- и 4-часового теплового стресса. Нsps обнаружены у двух видов немертин. У L. alborostratus Hsp70 и Нsp90-иммунореактивность обнаружена в стенке тела в клетках эпидермиса и кутиса, а также в эпителии желудка и хобота, при температурном стрессе Нsр-иммунореактивность в этих клетках и тканях выше по сравнению с контрольной группой. $V$ Q. stimpsoni в контроле и при тепловом стрессе Нsp70 и Нsp90 выявляются в эпидермисе, кроме того при стрессе низкая иммунореактивность выявляется в эпителии желудка и в нервных клетках боковых нервных стволов. У L. alborostratus при тепловом стрессе наблюдается увеличение Нsp70 и Нsp90 иммунореактивности в хоботе. Увеличение иммунореактивности эпидермального гранул выявляется в обоих видов немертин, особенно $Q$. stimpsoni. Накопление Hsp70 и Нsp90 в стенке тела и гастроэпидермисе немертин может указывать на их важную роль в физиологичесой устойчивости к термальному стрессу.

Как цитировать эту статью: Chernyshev A.V., Kotsyuba E.P., Okazaki R.K. 2018. Thermal induction of heat shock proteins Hsp70 and Hsp90 in tissues of the nemerteans Lineus alborostratus Takakura, 1898 and Quasitetrastemma stimpsoni (Chernyshev, 1992) // Invert. Zool. Vol.15. No.1. P.51-70. doi: 10.15298/invertzool.15.1.04

КЛЮЧЕВЫЕ СЛОВА: Нsp70, Нsp90, тепловой стресс, немертины, иммуногистохимия.

\section{Introduction}

Elevated temperatures even a few degrees above optimal can cause living proteins of organisms to unfold, entangle, and aggregate nonspecifically (Richter et al., 2010). Heat shock response of cells and tissues presumably is not affected directly by temperature but to the accumulation of these unfolded proteins (Richter $e t$ al., 2010). Arrigo (2000) reported that organisms respond to lethal effects of hyperthermia through protection of heat shock proteins (Hsps), a family of highly conserved proteins that are found in all organisms from prokaryotes to mammals (Hunt, Morimoto, 1985; Lindquist, 1986; Fast et al., 2002; Chen et al., 2015). Hsps are necessary for the normal functioning of the cell structures in response to environmental stresses (Lindquist, Craig, 1988; Sanders, 1993; Feder, Hofmann, 1999; Oyake et al., 2006).

The number categorization of each Hsp depends on the molecular weight $(\mathrm{kDa})$, with each family containing individual protein isoforms. The more commonly recognized proteins are Hsp60, Hsp70, Hsp90, and Hsp100 (Parsell, Lindquist, 1993; Moseley, 1997; Borkan, Gullans, 2002), with Hsp70 and Hsp90 being the most ubiquitous of the Hsps.

Under normal conditions, Hsp70 contributes to the synthesis of new proteins in the cytosol and cell organelles (Mayer, Bukau, 2005). Hsp90, found in high concentrations in the cytosol, binds to native but not unfolded proteins (Richter et al., 2010). Under thermal stress Hsp70 and Hsp90 prevent aggregations of unfolded proteins (Richter et al., 2010) and 
refolding of damaged proteins (Glover, Lindquist, 1998; Maloyan et al., 1999; Young et al., 2004). Furthermore, Hsp70 may refold aggregated proteins (Mayer, Bukau, 2005) while Hsp90 may be important in holding protein intact (Richter et al., 2010).

Hsp70 consists of three functional domains, ATP-dependent chaperones have a conserved $\mathrm{N}$-terminal ATPase domain, a substrate binding domain, and a variable C-terminal region. Eukaryotic Hsp90 proteins have functionally conserved $\mathrm{N}$-termini and C-termini connected by a middle region containing highly charged and hydrophobic regions with variable length (Pratt, Toft, 2003). Conserved sequences for Hsp70 and Hsp90 have been identified in human, mouse, rat, insects, nematodes, yeasts, plants, and virus (Hunt, Morimoto, 1985; Choi et al., 2008; Liang et al., 2013; Chen et al., 2015). The sequence identities ranged from 76.7 to $80.7 \%$ for Hsp70 and 73.8 to $77.6 \%$ for Hsp90 between human and nematodes (Chen et al., 2015).

In invertebrates, Hsp is induced by various environmental factors, including osmotic (Tirard et al., 1997; Okazaki et al., 2006) and oxidative stress (Mager et al.á 2000), hypo- and hyperthermia, anoxia/hypoxia (Chang et al., 2000), and heavy metal pollution (Piano et al., 2004; Pruski, Dixon, 2007; Lilja et al., 2008). The physiological responses of these invertebrates allow them to be considered as biomarkers of stress (Ackerman et al., 2000; Bierkens, 2000).

Temperature is one of the major factors influencing the functional state of marine invertebrates on all levels of biological organization, including molecular (Hochachka, Somero, 2002), and can lead to the damage of proteins (Hamdoun et al., 2003). Two distinct Hsp families, Hsp70 and Hsp90, are currently recognized to have a central role in response against thermal stress; their presence under thermal stress has been found in many organs and tissues of invertebrates from various taxonomic groups (Sanders et al., 1991; Hofmann, Somero, 1996; Clegg et al., 1998; Tomanek, Somero, 1999; Spees et al., 2002; Boutet et al., 2003; Hamdoun et al., 2003). The cytoprotective function of Hsp allows the nematode Caenorhabditis elegans to be highly resistant to a variety of environmental stress stimuli (Prahlad et al., 2008).

In the nemertean Paranemertes peregrina Hsp70 and Hsp90 were easily induced by heat and osmotic stresses, resulting in expression level detected by immunoblot (Okazaki et al., 2001, 2006). However, very little is known about both Hsp70 and Hsp90 in response to thermal stress in other species of nemerteans. In Vostok Bay in the Sea of Japan, two different taxonomic orders of nemerteans, Lineus alborostratus Takakura, 1898 (Heteronemertea: Lineidae) and Quasitetrastemma stimpsoni (Chernyshev, 1992) (Hoplonemertea: Tetrastemmatidae) co-exist. L. alborostratus has been found in habitats varying in temperatures from $-2^{\circ} \mathrm{C}$ in winter to $24^{\circ} \mathrm{C}$ in summer; whereas $Q$. stimpsoni has adapted to higher temperatures (Chernyshev, 2014). Chernyshev (2014) reported two different reproductive temperatures: 10 $15^{\circ} \mathrm{C}$ for L. alborostratus and $20-22^{\circ} \mathrm{C}$ for $Q$. stimpsoni. Thus, we hypothesize that the two species would show differences in Hsp70 and Hsp90 responses in reflecting their varying ecological thermal environments. Additionally, distribution of these Hsps in nemertean tissues has not been reported. To address this lack of information, immunohistochemistry was used to determine the distribution of Hsp70 and Hsp90 in the tissues of L. alborostratus and Q. stimpsoni under thermal stress. Identification of specific tissues involved in stress response may be helpful in understanding a role of Hsp in the protection of ribbon worms in their fluctuating thermal environments.

\section{Materials and Methods}

\section{Experimental materials}

Adult specimens of Lineus alborostratus and Quasitetrastemma stimpsoni were collected in intertidal zone of Vostok Bay $\left(42^{\circ} 52^{\prime} 33^{\prime \prime} \mathrm{N}\right.$, $\left.132^{\circ} 44^{\prime} 35^{\prime \prime} \mathrm{E}\right)$ in the Sea of Japan in June 2013. The ribbon worms were acclimated in an aerated seawater aquarium $\left(5^{\circ} \mathrm{C}\right.$ at $33 \%$ ) for three 
weeks. Good ethical procedures have been followed in the care, housing, and use of the animals in our study in accordance to the European Communities Council Directive of 24 November 1986 (86/609/EEC). In the experiment, 36 nemerteans were divided into three treatments: a control group (6 specimens of each species) was maintained at a temperature of $5^{\circ} \mathrm{C}$ and two experimental treatments ( 6 specimens of each species) were each exposed to thermal stress $\left(22^{\circ} \mathrm{C}\right)$ for $2 \mathrm{~h}$ and $4 \mathrm{~h}$. This temperature was selected after experimental observations that determined the lethal temperature to be $26-$ $27^{\circ} \mathrm{C}$. The maximum of $4-\mathrm{hr}$ duration of the thermal-stress experiment was selected based on preliminary testing that revealed that the rapid rise from $5^{\circ} \mathrm{C}$ to $22^{\circ} \mathrm{C}$ was sub-lethal after $4-5 \mathrm{~h}$ for both nemertean species and lethal after $6 \mathrm{~h}$ for $Q$. stimpsoni and 7-8 h for L. alborostratus.

\section{Western immunoblotting}

For western blotting, three specimens of each species from each treatment were homogenized (1:5) in the buffer containing $20 \mathrm{mM}$ Tris- $\mathrm{HCl}$ (pH 7.5), $0.1 \mathrm{mM}$ EDTA, $0.5 \mathrm{mM}$ dithiothreitol (DTT), and $0.2 \mathrm{mM}$ phenylmethylsulfonyl fluoride (PMSF). After centrifugation $\left(15,000 \mathrm{~g}\right.$ at $\left.4^{\circ} \mathrm{C}, 20 \mathrm{~min}\right)$, the supernatant was separated, and the total protein concentration was determined by the Lowry method (Lowry et al., 1951). Then, $40 \mu \mathrm{g}$ of proteins were separated by $12 \%$ SDS-polyacrylamide gel electrophoresis (PAGE) at $150 \mathrm{~V}$ for $1 \mathrm{~h}$. After electrophoresis, the proteins were transferred onto a nitrocellulose membrane (Sigma-Aldrich, USA) and left overnight in $0.01 \mathrm{mM}$ TBS (0.01 mM Tris- $\mathrm{HCl}$ buffer, $\mathrm{pH} 8.0,0.15 \mathrm{~mol}^{-1}$ $\mathrm{NaCl}$ ) containing $4 \%$ bovine serum albumin (BSA). The membranes were rinsed in distilled water and incubated with mouse monoclonal antibodies against Hsp70 (Abcam, UK; Cat. \#2787) or Hsp90 (Abcam, UK; Cat. \#1429) diluted 1:1000 in TBS containing 1\% BSA for $3 \mathrm{~h}$ at $4^{\circ} \mathrm{C}$. After washing in TBS, the membranes were incubated with horseradish-peroxidase conjugated secondary antibodies (dilu- tion 1:200, Vector Labs, USA; Cat. \#PK-6200) for $1 \mathrm{~h}$ at room temperature. Peroxidase reaction was visualized using a VIP Substrate Kit (Vector Labs, USA). The membranes were washed and scanned. Molecular mass determinations were based on prestained molecular mass markers (GeneDirex, Inc., USA).

\section{Immunohistochemical detection}

For immunohistochemical detection of Hsp70 and Hsp90, the remaining 18 nemerteans were fixed whole in $4 \%$ paraformaldehyde in $0.1 \mathrm{M}$ phosphate buffer solution (PBS) ( $\mathrm{pH} 7.2$ ) for $2 \mathrm{~h}$ at $4^{\circ} \mathrm{C}$. After washing in PBS, they were placed for 1 day in a cold solution (30\%) of sucrose in $0.1 \mathrm{M}$ PBS. Hsp70 and Hsp90 were detected using the methods developed by Chernyshev \& Kotsyuba (2014). Thick sections $(\sim 30-35 \mu \mathrm{m})$ were cut on a freezing microtome and mounted on polylysine-coated slides. After inhibition of endogenous peroxidase in $1 \% \mathrm{H}_{2} \mathrm{O}_{2}$ and suppression of non-specific binding of antibodies in $1 \%$ normal goat serum, the sections were then incubated with mouse monoclonal antibodies against Hsp70 or Hsp90 (1:500; Abcam, UK) for $18 \mathrm{~h}$ at $4{ }^{\circ} \mathrm{C}$, which shows cross-reactivity with mouse, rat, rabbit, cow, human, Saccharomyces cerevisiae, bird, Drosophila melanogaster, fish, and amphibians (Monribot-Villanueva et al., 2013; Zhang et al., 2015; Mario et al., 2016). The sections were washed in three changes of $0.1 \mathrm{M}$ PBS (pH 7.2) and incubated with biotinylated secondary antibodies against mouse immunoglobulin (Ig) (1:200) (Vector Labs, USA; Cat. \#PK-6200) for $2 \mathrm{~h}$. After washing, all of the sections were then incubated with anavidin-biotin-peroxidase complex (Vectastain Elite ABC Kit, Vector Labs, USA; Cat. \#PK-6200) for $1 \mathrm{~h}$ at $22^{\circ} \mathrm{C}$ in the dark and then washed thrice in PBS. The reaction products were visualized using a substrate (VIP Substrate Kit, Vector Labs, USA; Cat. \#SK4600). Afterwards, the sections were washed in three changes of PBS, dehydrated through an ethanol series of increasing concentrations, and mounted in Canadian balsam. The corresponding negative control sections were prepared by 




Fig. 1. Western immunoblots of Hsp70 and Hsp90 in Lineus alborostratus and Quasitetrastemma stimpsoni in the (control) 0-, 2- and 4-h thermal stress. A - Hsp70; B - Hsp90.

Abbreviations: Lane M - pre-stained molecular mass standards, kDa; Lane 1 - control group 0-h; Lane 2 - 2-h thermal stress; Lane 3 - 4-h thermal stress.

Рис. 1. Вестерн-иммуноблоттинг Нsp70 и Нsp90 у Lineus alborostratus и Quasitetrastemma stimpsoni (контроль) 0-, 2- и 4-часовой тепловой стресс. А - Hsp70; В - Hsp90.

Обозначения: дорожка М - преокрашенные стандарты молекулярной массы, кД; дорожка 1 - контрольная группа 0 ч; дорожка $2-2$-часовой тепловой стресс; дорожка 3 - 4-часовой тепловой стресс.

omitting the primary antibody (Huang et al., 2005; Bao et al., 2008). The immunohistochemically-stained sections were photographed on an Axiovert $200 \mathrm{M}$ inverted microscope (Zeiss, Göttingen, Germany) with a digital microscopy camera (Zeiss AxioCam HRC, Göttingen, Germany).

The number of Hsp70- and Hsp90-positive cells in specific nemertean tissues was estimated using an automatic image analysis system Allegro-MC (Afanasyev et al., 2002). The system included an ERMA-2 microscope (Japan) equipped with a CREATIVE video camera (Japan) and IBM-compatible computer with a video capture card ATI-128 pro (32 MB, $1280 \times$ 1024 pixel). In each section, Hsp70 and Hsp90 immunoreactive cells were counted in five randomly selected fields of vision using VideoTest
5.0 software (VideoTest Software, St. Petersburg, Russia) to obtain a percentage (number of immunoreactive cells/total cells counted). For each tissue, Hsp70 and Hsp90 immunoreactive cells were then counted from 10 histological sections.

\section{Statistical analysis}

All percentages were converted by taking their square roots and then calculating their $\arcsin$ values. These transformed values were statistically analyzed by one-way ANOVA followed by Tukey's multiple comparison test (Vassarstats Program) to determine significant differences ( $\mathrm{P}<0.05)$ among the control, 2-h, and 4-h treatments (Sokal, Rolhf, 1994). 


\section{Results}

\section{Western immunoblotting}

The immunoblots revealed apparent differences in the concentrations of Hsp70 and Hsp90 between the two ribbon worm species from the control and thermally-stressed treatments. With equal starting protein loadings $(40 \mu \mathrm{g})$ in the control for both species, the bands of both Hsp70 and Hsp90 were markedly present in $L$. alborostratus but barely noticeable in $Q$. stimpsoni (Fig. 1A, B). After 2-h and 4-h thermal stress for L. alborostratus, Hsp70 appeared to show a weak increase compared to the controls while for Q. stimpsoni, Hsp70 showed a marked increase after 4-h thermal stress. In $L$. alborostratus Hsp90 bands were moderately visible at 2-h thermal stress but after 4-h stress its concentrations appeared to increase dramatically. In Q. stimpsoni the amount of Hsp appeared to be quite low as the bands were barely discernible.

\section{ControlHsp70 immunohistochemistry}

Immunohistochemical analysis revealed Hsp70 and Hsp90 in both nemertean species; however, their tissue distributions in the control and thermally-stressed worms differed (Figs. 27). For the control Q. stimpsoni, immunoreactivity was generally detected in the epidermal cells of the anterior of worm, particularly the precerebral region but was rarely found in the posterior region. In L. alborostratus Hsp70 immunoreactivity was detected in the epidermal cells of all regions. Hsp70 immunoreactivity was not observed around the stomach cells of $L$. alborostratus (Fig. 2A) and Q. stimpsoni (Fig. 2B). The negative controls did not bind nonspecifically to any cell or tissue of L. alborostratus (Fig. 2A) and Q. stimpsoni (Fig. 2B). However, for the two nemertean species, positive Hsp70 immunoreactivities were detected in the epidermal cells (Fig. 2E, F) and supraepidermal granules (i.e. compact particles on the epidermal surface) and localized separately or in small clusters (Fig. 2C, D). In L. alborostratus, Hsp70 immunoreactivities were also observed in the stomach epithelia but not around the stomach walls (Fig. 2G) and in the separate cells of the proboscis epithelium (Fig. 2H).

\section{Thermal stress Hsp70 immunohis- tochemistry}

After 2-h thermal stress in Q. stimpsoni, Hsp70 immunoreactivity appeared to increase

Fig. 2. Distribution of Hsp70 in Lineus alborostratus and Quasitetrastemma stimpsoni. A — L. alborostratus, negative control section showing no Hsp70-immunoreactivity; B - Q. stimpsoni, negative control section showing no Hsp70-immunoreactivity; $\mathrm{C}$ - L. alborostratus, positive control section showing the presence of Hsp70 immunoreactivity in the stomach region of L. alborostratus; D, E - Q. stimpsoni, positive control section showing the presence of Hsp70 immunoreactivity (white arrows) in the basal epidermal layer of $Q$. stimpsoni; F - Hsp70-immunoreactivity in the epidermis of L. alborostratus; G - stomach of L. alborostratus; $\mathrm{H}$ - proboscis epithelium of L. alborostratus after 0 -h thermal stress. Black arrows indicate immunoreactive supra-epidermal granules, arrowheads show cephalic glands.

Abbreviations: ct - cutis; d - dermis; ep - epidermis; gep — gastral epithelium; $\mathrm{m}$ - body musculature; pge — proboscis gland epithelium; pr - proboscis; st - stomach. Scale bar: A - $50 \mu \mathrm{m}$; B-D - $100 \mu \mathrm{m}$; E-H $-50 \mu \mathrm{m}$. Рис. 2. Распределение Hsp70 у Lineus alborostratus and Quasitetrastemma stimpsoni. A — L. alborostratus, негативный контроль показывает отсутствие Нsp70-иммунореактивности в области желудка; В - $Q$. stimpsoni, негативный контроль показывает отсутствие Нsp70-иммунореактивности в области желудка; C - L. alborostratus, позитивный контроль показывает Нsp70-иммунореактивность в области желудка; D, E - Q. stimpsoni, положительный контроль показывает наличие Нsp70-иммунореактивности (белые стрелки) в базальной части эпидермиса; F — распределение Нsp70-иммунореактивности в контроле в эпидермисе у L. alborostratus; G — желудок L. alborostratus; Н — эпителий хобота L. alborostratus, контрольная группа 0 ч.

Черные стрелки указывают на иммунореактивные гранулы на поверхности эпидермиса, наконечники стрелок указывают на головные железы.

Обозначения: ct - кутис; d - дермис; ер — эпидермис; gep - гастроэпителий; m - мускулатура стенки тела; pge - эпителий хобота; st - желудок. Масштаб: A Ï 50 мкм; B-D - 100 мкм; E-H - 50 мкм. 







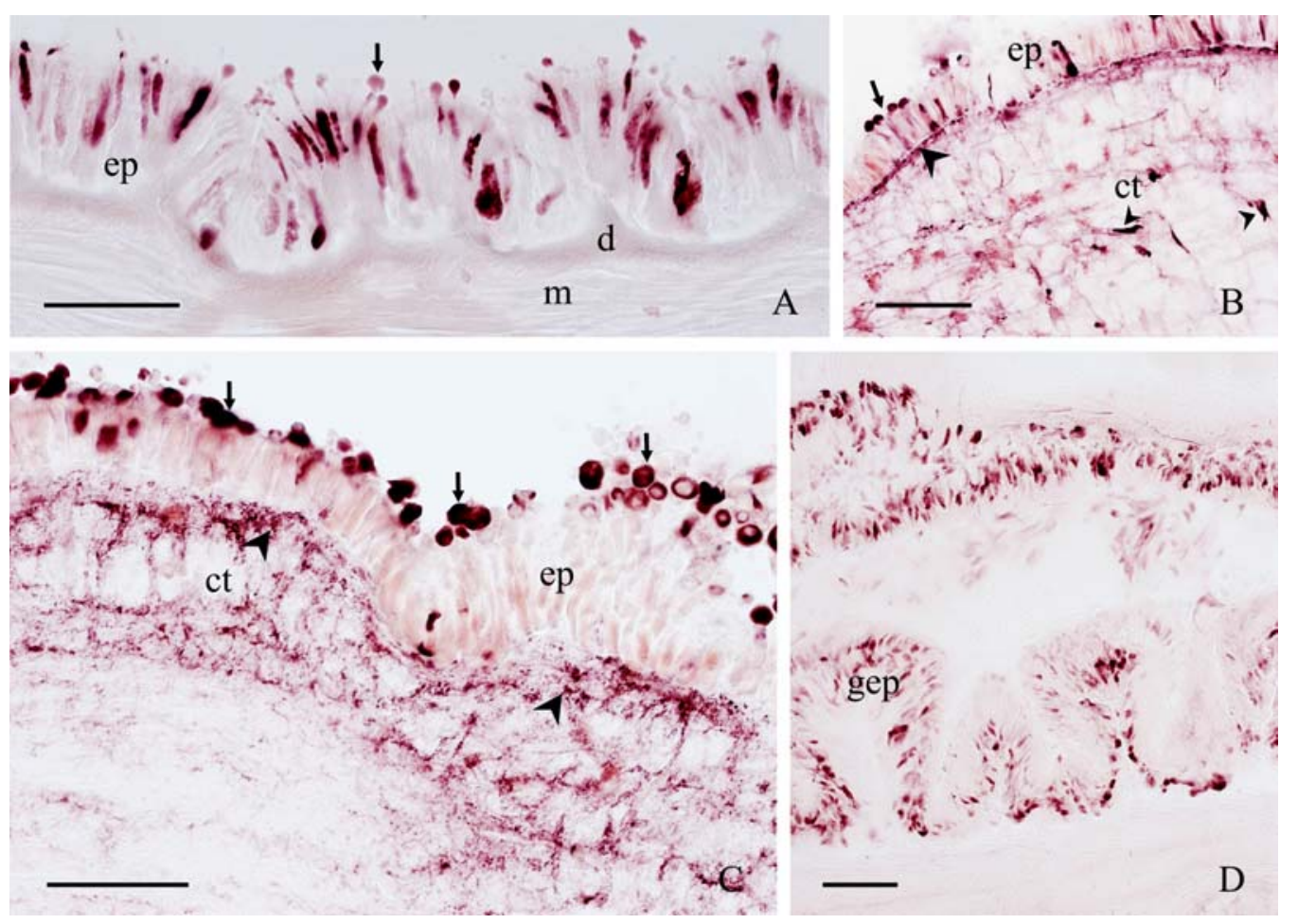

Fig. 3. Distribution of Hsp70 immunoreactivity in Lineus alborostratus and Quasitetrastemma stimpsoni in the body wall and digestive system after 2-h thermal stress. A - Q. stimpsoni; B-D - L. alborostratus; $\mathrm{A}-\mathrm{C}$ - the body wall; D - digestive system. Arrows indicate immunoreactive supra-epidermal granules, larger arrowheads show subepithelial glands, smaller arrowheads indicate subepithelial layer ("plexus"). Abbreviations: ct — cutis; d — dermis; ep — epidermis; gep — gastral epithelium; $\mathrm{m}$ — body musculature. Scale bars: $50 \mu \mathrm{m}$.

Рис. 3. Распределение Нsp70-иммунореактивности у Quasitetrastemma stimpsoni и Lineus alborostratus в стенке тела и пищеварительной системе после 2-часового теплового стресса. А $-Q$. stimpsoni; $\mathrm{B}-$ $\mathrm{D}$ - L. alborostratus; A-C — стенка тела; D — пищеварительная система.

Стрелки указывают на иммунореактивные гранулы, большие наконечники стрелок указывают на субэпителиальные железы, маленькие наконечники стрелок указывают на субэпидермальный слой.

Обозначения: ct — кутис; d — дермис; ep — эпидермис; gep — гастроэпителий; $\mathrm{m}$ - мускулатура стенки тела. Масштаб: 50 мкм.

substantially in some areas of the epidermis, specifically, the release of Hsp70-immunoreactive granules were observed on the surface of the epidermal cells (Fig. 3A). In L. alborostratus Hsp70 immunoreactivity of separate cells in the epidermis appeared to show little increase (Fig. 3B). However, intensive reaction was observed in the small non-glandular cells (4-7 $\mu \mathrm{m}$ in diameter) of the thin subepidermal layer of the extracellular matrix and larger glandular cells (12-20 $\mu \mathrm{m}$ long), which were localized deep in the cutis in the anterior body part, predominantly in the precerebral region (Fig. 3B, C). Moreover, the aggregations of Hsp70 immunoreactive granules $(6-10 \mu \mathrm{m})$ appeared on the surface of the epidermis; their number and intensity of staining varied in different parts of the body (Fig. 3B, C). In the digestive system of L. alborostratus, Hsp70 immunoreactivity in the epithelial cells of the stomach and intestine showed an increase compared to the control (Fig. 3D).

After 4-h thermal stress in Q. stimpsoni, Hsp70 immunoreactivity increased in the distal 


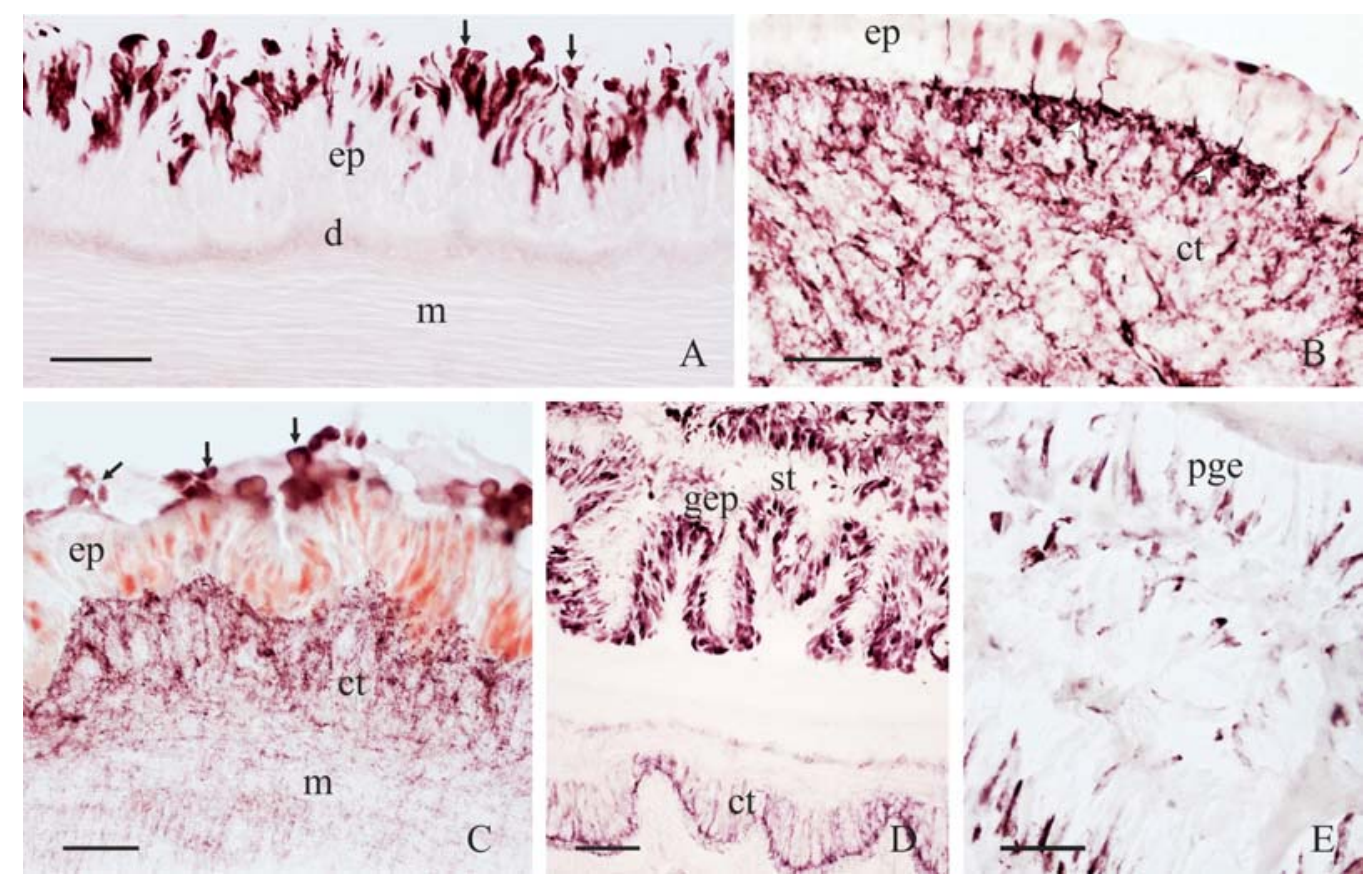

Fig. 4. Distribution of Hsp70 immunoreactivity in Lineus alborostratus and Quasitetrastemma stimpsoni in the body wall, digestive system, and proboscis after 4-h thermal stress. A $-Q$. stimpsoni; B-E $-L$. alborostratus; A-C - in the body wall; D - digestive system; E - proboscis. Arrows indicate immunoreactive supra-epidermal granules, arrowheads show subepithelial layer.

Abbreviations: ct — cutis; $\mathrm{d}$ - dermis; ep — epidermis; gep — gastral epithelium; $\mathrm{m}$ - body musculature; st stomach; pge - proboscis gland epithelium. Scale bars: $50 \mu \mathrm{m}$.

Рис. 4. Распределение Нsp70-иммунореактивности у Quasitetrastemma stimpsoni и Lineus alborostratus в стенке тела, пищеварительной системе и хоботе после 4-часового теплового стресса. А $Q$. stimpsoni, B-E - L. alborostratus, A-C - стенка тела; D - пищеварительная система; Е - хобот. Стрелки указывают на иммунореактивные супраэпидермальные гранулы, наконечники стрелок указывают на субэпителиальный слой.

Обозначения: ct — кутис; d — дерма; ер — эпидермис; gep — гастроэпителий; $\mathrm{m}$ — мускулатура стенки тела; pge - эпителий хобота; st - желудок. Масштаб: 50 мкм.

part of epidermis (Fig. 4A). In L. alborostratus, Hsp70 immunoreactivity was observed in the isolated epidermal cells (Fig. 4B, C). Hsp70 immunoreactive material was evenly distributed over the apical surface of the epidermis (Fig. 4C) as aggregations of Hsp70 immunoreactive granules were only found in some areas. Also in the cutis, the immunoreactivity increased; with the highest amount observed in the anterior part of the body, mainly in the precerebral region (Fig. 4B). Hsp70 immunoreactivity also appeared in the body wall musculature (Fig. 4C). In the digestive system, the number and intensity of staining of Hsp70 immunoreactive cells in the stomach epithelium increased (Fig. 4D); extracellular distribution of immunoreactive material was observed in the lumen of the stomach. Hsp70 immunoreactivity was detected mainly in the proximal part of the glandular epithelium of the proboscis (Fig. 4E).

\section{Control Hsp90 immunohistoche-} mistry

For the control Q. stimpsoni, Hsp90 was revealed in the epidermal cells and secretory granules on the epidermal surface (Fig. 5A). In L. alborostratus, Hsp90 was detected in the 




Fig. 5. Control Hsp90 immunoreactivity in Quasitetrastemma stimpsoni and Lineus alborostratus in the body wall, stomach, and proboscis. A - Q. stimpsoni; B-E - L. alborostratus; A, C, D - body wall; B — body wall, stomach and proboscis; E - proboscis. Arrows indicate immunoreactive supra-epidermal granules. Abbreviations: ct — cutis; $\mathrm{d}$ - dermis; ep — epidermis; $\mathrm{m}$ — body musculature; pge — proboscis gland epithelium; st — stomach. Scale bars: $50 \mu \mathrm{m}$.

Рис. 5. Нsp90-иммунореактивность в стенке тела, желудке и хоботе у Quasitetrastemma. stimpsoni и Lineus alborostratus в контроле. А - Q. stimpsoni; В-E - L. alborostratus; A, С, D - стенка тела; В стенка тела, желудок и хобот; Е - хобот.

Стрелки указывают на иммунореактивные супраэпидермальные гранулы.

Обозначения: ct — кутис; d — дерма; ep — эпидермис; $\mathrm{m}$ - мускулатура стенки тела; pge — эпителий хобота; st - желудок. Масштаб: 50 мкм. 

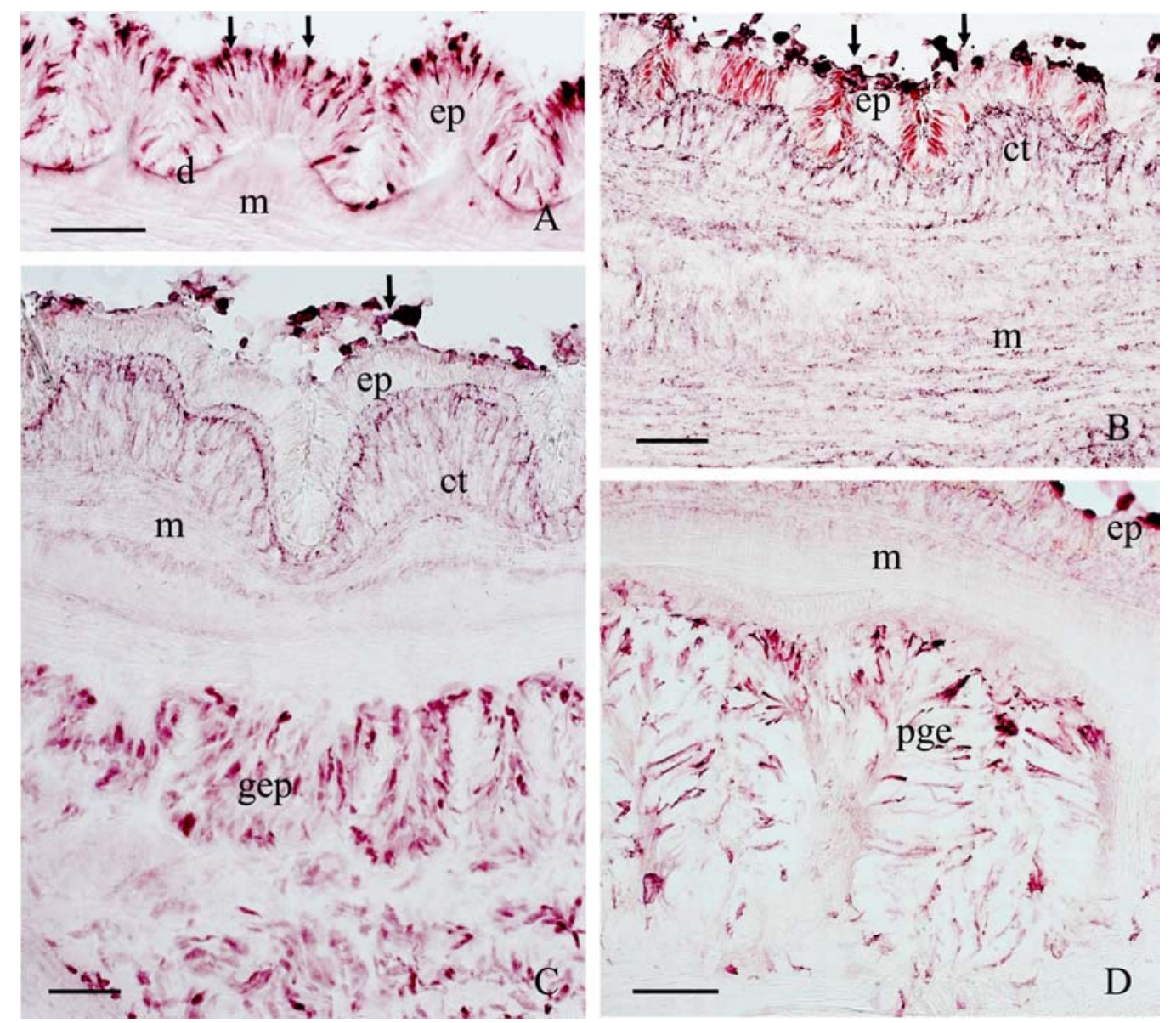

Fig. 6. Distribution of Hsp90 in Lineus alborostratus and Quasitetrastemma stimpsoni after 2-h thermal stress. A - Q. stimpsoni; B-D - L. alborostratus. A-B - body wall; $\mathrm{C}$ - body wall and stomach; D — proboscis. Arrows indicate immunoreactive supra-epidermal granules. Abbreviations: ct — cutis; $\mathrm{d}$ - dermis; ep — epidermis; $\mathrm{m}$ - body musculature; gep — gastral epithelium; pge — proboscis gland epithelium. Scale bars: $50 \mu \mathrm{m}$.

Рис. 6. Распределение Нsp90 у Quasitetrastemma stimpsoni и Lineus alborostratus после 2-часового теплового стресса. А - Q. stimpsoni; B-D - L. alborostratus. А-В - стенка тела; С - стенка тела и желудок; D - хобот.

Стрелки указывают на иммунореактивные супраэпидермальные гранулы. Обозначения: ct — кутис; $\mathrm{d}$ — дерма; ep - эпидермис; gep — гастроэпителий, m - мускулатура стенки тела; pge — эпителии хобота; st — желудок. Масштаб: 50 мкм.

body wall, stomach, and proboscis (Fig. 5B). In the body wall, Hsp90 immunoreactivity was revealed in the cutis (Fig.5C). Besides, granules of 5-10 $\mu \mathrm{m}$ were intensively marked over the entire epidermal surface (Fig. 5B-D). In the digestive system, Hsp90 immunoreactive cells were revealed in the stomach epithelium (Fig. 5B). In the proboscis, Hsp90 immunoreactivity was detected in the glandular epithelium (Fig. 5B, E).
Thermal stress Hsp90 immunohistochemistry

In 2-h thermally-stressed Q. stimpsoni, the number and intensity of staining of Hsp90 immunoreactive cells increased in the body wall, mainly in its distal part (Fig. 6A). In L. alborostratus a slight increase in the staining intensity of cells in the cutis and the subepidermal layer was observed (Fig. 6B). Besides, numerous 
Hsp90-immunoreactive granules were detected on the epidermal surfaces. In the digestive system, the number of Hsp90 immunoreactive cells increased in the glandular cells with the basal part of the epithelium stained most intensively (Fig. 6C). Pronounced Hsp90 immunoreactivity was also observed in the glandular epithelium of the proboscis (Fig. 6D).

In the 4-h thermally-stressed Q. stimpsoni, Hsp90 immunoreactivity was revealed in the distal part of the epidermis (Fig. 7A). Hsp90 immunoreactivity appeared in single neurons of the lateral nerve cords (Fig. 7B), in cells of the stomach (Fig. 7C), and in the proboscis (Fig. 7D). Low immunoreactivities were detected in the proboscis, stomach, and lateral nerve cord. In L. alborostratus, a number of Hsp90-immunoreactive cells increased in the cutis (Fig. 7E). In the digestive system, Hsp90 immunoreactivity was visibly present in the gastric epithelium and in the lumen of the stomach (Fig. 7F). Additionally, faint Hsp90 immunoreactivities were observed at the boundary of the lateral nerve cords and outer longitudinal musculature (Fig. 7E).

\section{Statistical analysis}

The results of the statistical analysis are tabulated in Table 1. The epidermis showed marked differences in the Hsp immunoreactivities between the two ribbon-worm species (Fig. 8). In Q. stimpsoni, Hsp immunoreactivities were revealed locally within the epidermis (47$69 \%$ for Hsp70 and 38-55\% for Hsp90), resulting in very highly significant differences $(\mathrm{P}<0.001)$ among the treatments (Fig. 8A). However, L. alborostratus showed no significant differences $(\mathrm{P}=0.09)$ in immunoreactivities of Hsp70 (19-20\%) and Hsp90 (10-15\%) among three treatments (Fig. 8D). For both species, the Hsp70 and Hsp90 immunoreactivities in the controls ranged from $11-20 \%$. Interestingly, Hsp immunoreactivity of the supraepidermal granules were observed to increase significantly $(\mathrm{P}<0.0001)$ at $2-\mathrm{hr}$ in both the anterior and mid to posterior halves of $Q$. stimpsoni (Fig. 8B, C) and in L. alborostratus
(Fig. 8E). In other tissues of L. alborostratus, significant differences $(\mathrm{P}<0.0001)$ in immunoreactivities were found (Fig. 9). For the subepithelial glands (Fig. 9A), a high Hsp70 immunoreactivity $(53 \%)$ was detected in the $4-\mathrm{hr}$ treatment. Similarly, in both the 2-h and 4-hr treatments, Hsp90 immunoreactivities were high $(55 \%)$. The cutis cells showed high immunoreactivities, 63 and 39\%, at 4-h treatments for Hsp70 and Hsp90, respectively (Fig. 9B). The most dramatic changes were detected in the stomach for 2-hr to 4-hr thermal stress; Hsp70 and Hsp90 immunoreactivities increased from 44 to $93 \%$ and 39 to $83 \%$, respectively (Fig. 9C). High immunoreactivities, $36 \%$ for Hsp70 in the proboscis, were detected at 4-h treatment; whereas, for Hsp90, immunoreactivities of 24 and $26 \%$ did not differ between the 2-h and 4-hr treatments (Fig. 9D). Since no Hsp70 and Hsp90 immunoreactivities were detected in the lateral nerve cord of L. alborostratus and only Hsp90 at the 4-h treatment, statistical analysis was not performed for this tissue.

\section{Discussion}

This study showed the presence of Hsp70 and Hsp90 immunoreactivities in the tissues of intact L. alborostratus and Q. stimpsoni. Considerable differences in immunoreactivities of the two Hsps were observed between the two ribbon-worm species. Detection of Hsp70 and Hsp90 in both L. alborostratus and Q. stimpsoni confirms the previous report of these two Hsps in thermally stressed Paranemertes peregrina (Okazaki et al., 2001). Although the immunoblots showed very little Hsp70 and Hsp90 concentrations for $Q$. stimpsoni, the immunohistochemical analysis revealed the epidermis as its most sensitive tissue when compared to that of L. alborostratus. Other tissues of Q. stimpso$n i$ showed very little or no Hsp immunoreactivities, while those other tissues of L. alborostratus were quite immunoreactive to the both Hsps.

Evgen'ev et al. (2007) reported varying Hsp concentrations in thermally stressed invertebrates depend on a number of factors, the species of animal, the type of cell and tissue, and the 
Table 1. Results of the one way ANOVA statistical analysis of the percentages of Hsp70 and Hsp90 immunoreactivities in the different tissues and the supra-epidermal granules of Lineus alborostratus and Quasitetrastemma stimpsoni.

Таблица 1. Результаты однофакторного статистического анализа (ANOVA) процентных значений иммунореактивности Hsp70 и Hsp90 в различных тканях и супраэпидермальных гранулах Lineus alborostratus and Quasitetrastemma stimpsoni.

\begin{tabular}{|c|c|c|c|c|c|c|}
\hline & $\mathbf{P}$ & $\begin{array}{c}F \\
\text { value }\end{array}$ & df & $\mathbf{n}$ & Tukey HSD & \\
\hline \multicolumn{7}{|l|}{ L. alborostratus Hsp70 } \\
\hline epidermis & 0.0900 & 2.6 & 2 & 30 & ns & \\
\hline subepithelial glands & 0.0001 & 455.6 & 2 & 30 & $4.9(\mathrm{P}<0.01)$ & \\
\hline cutis & 0.0001 & 4184.9 & 2 & 30 & $4.8(\mathrm{P}<0.01)$ & \\
\hline stomach & 0.0001 & 246.1 & 2 & 30 & $6.8(\mathrm{P}<0.01)$ & \\
\hline proboscis & 0.0001 & 48.8 & 2 & 15 & $7.6(\mathrm{P}<0.01)$ & \\
\hline granules & 0.0001 & 95.9 & 2 & 12 & $2.8(\mathrm{P}<0.01)$ & \\
\hline \multicolumn{7}{|l|}{ L. alborostratus Hsp90 } \\
\hline epidermis & 0.1100 & 2.5 & 2 & 30 & ns & \\
\hline subepithelial glands & 0.0001 & 183.3 & 2 & 30 & $6.1(\mathrm{P}<0.01)$ & ns: 2-h vs 4-h \\
\hline cutis & 0.0001 & 13.2 & 2 & 30 & $4.5(\mathrm{P}<0.01)$ & ns: Control vs 2-h \\
\hline stomach & 0.0001 & 228.8 & 2 & 30 & $6.3(\mathrm{P}<0.01)$ & \\
\hline proboscis & 0.0006 & 14.7 & 2 & 15 & $9.6(\mathrm{P}<0.01)$ & ns: 2 -h vs 4-h \\
\hline granules & 0.7426 & $0.3^{*}$ & 8 & 10 & ns & \\
\hline \multicolumn{7}{|l|}{ Q. stimpsoni Hsp70 } \\
\hline epidermis & 0.0001 & 223.3 & 2 & 30 & $4.9(\mathrm{P}<0.01)$ & \\
\hline $\begin{array}{l}\quad \text { supra-epidermal } \\
\text { granules } \\
\text { Q. stimpsoni Hsp90 }\end{array}$ & 0.0001 & 71.6 & 2 & 30 & $2.7(\mathrm{P}<0.01)$ & ns: 2 -h vs 4-h \\
\hline epidermis & 0.0001 & 73.4 & 2 & 30 & $5.6(\mathrm{P}<0.01)$ & \\
\hline $\begin{array}{l}\text { supra-epidermal } \\
\text { granules }\end{array}$ & 0.0079 & 6.1 & 2 & 25 & $4.0(\mathrm{P}<0.01)$ & ns: Control vs 2-h \\
\hline & & & & & & ns: Control vs 4-h \\
\hline
\end{tabular}

* t-value from t-test since 4-hr showed no but completely-fused granules.

temperature at which the cells (tissues, animals) were acclimatized before stress. In some invertebrate species, a high correlation between the tissue level of Hsp70 and their habitat temperatures has been found (Tomanek, Somero, 1999, 2000; Sørensen et al., 2005). Thus high Hsp concentrations in the control and thermally stressed L. alborostratus could be correlated with the ecological conditions of its habitat. This nemertean species lives predominantly in the intertidal zone of the Sea of Japan, where water temperatures can fluctuate greatly, e.g. from $-2{ }^{\circ} \mathrm{C}$ in winter to $+24^{\circ} \mathrm{C}$ in summer (Chernyshev, 2014). Moreover, in hyperthermia experiments with fruit fly Drosophila, higher Hsp70 concentrations were found in a population from a cold rather than from a warm climatic zone (Sørensen et al., 2001, 2005).

This study found accumulation of Hsp70 in the body wall, stomach, and proboscis after 2-h 


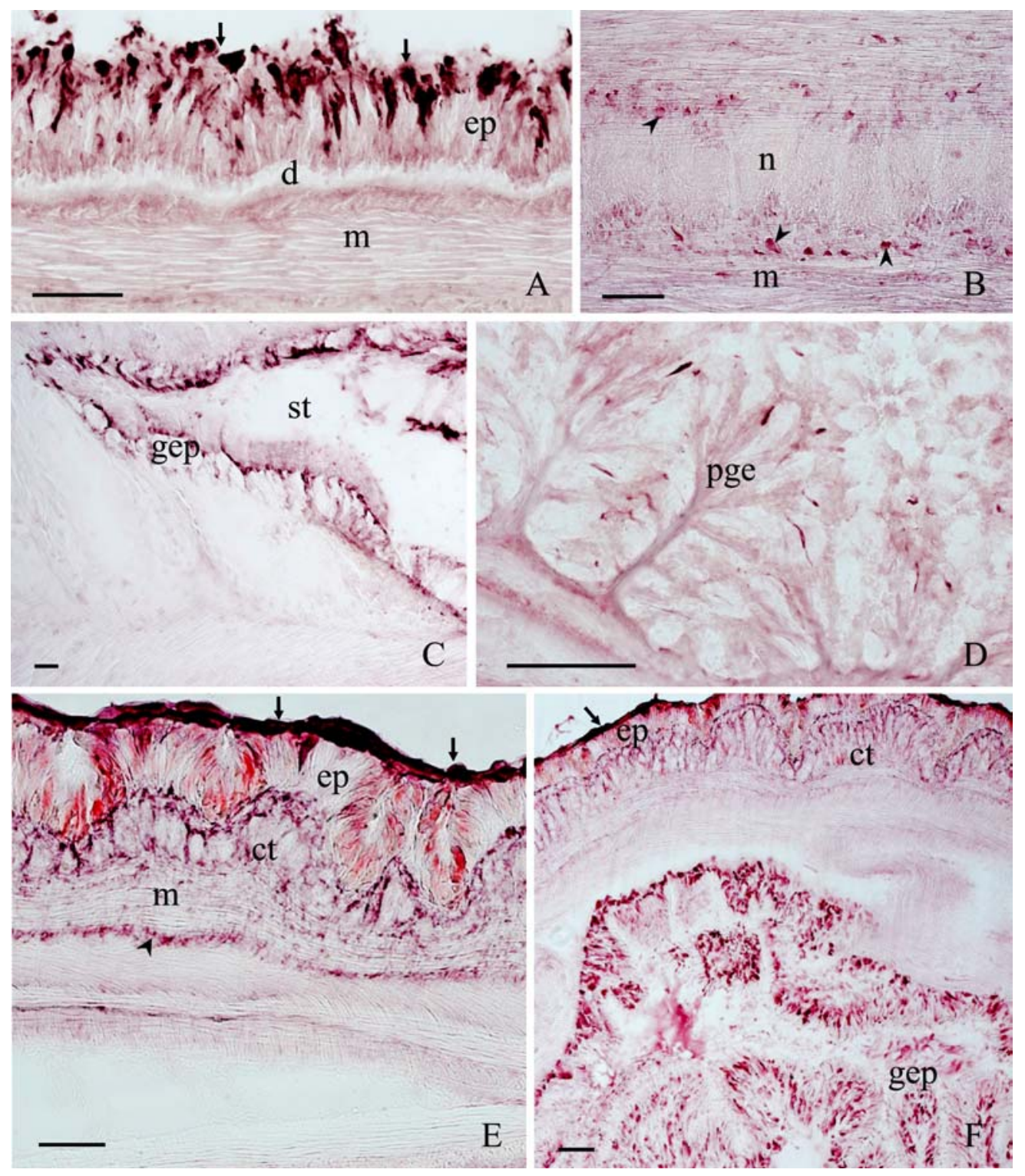

Fig. 7. Distribution of Hsp90 in Quasitetrastemma stimpsoni and Lineus alborostratus after 4-h thermal stress. A-D - Q. stimpsoni; E, F - L. alborostratus. A, E, F - body wall; B - lateral nerve; C, F stomach; D - proboscis.

Arrows indicate immunoreactive supra-epidermal granules, arrowheads show lateral nerve and neurones.

Abbreviations: ct — cutis; d — dermis; ep — epidermis; gep — gastral epithelium; ln — lateral nerve; $\mathrm{m}$ - body musculature; pge - proboscis gland epithelium; st — stomach. Scale bars: $50 \mu \mathrm{m}$.

Рис.7. Распределение Hsp90 у Quasitetrastemma stimpsoni и Lineus alborostratus после 4-часового теплового стресса. A-D - Q. stimpsoni; Е, F — L. alborostratus. A, E, F - стенка тела; В — боковые нервные стволы; C, F — желудок; D - хобот.

Стрелки указывают на иммунореактивные эпидермальные гранулы, наконечники стрелок указывают на боковой нервный ствол и нейроны.

Обозначения: ct — кутис; d — дерма; ер - эпидермис; gep — гастроэпидермис; $\ln$ - боковые нервные стволы; m - мускулатура стенки тела; pge — эпителий хобота; st — желудок. Масштаб: A-D - 50 мкм. 

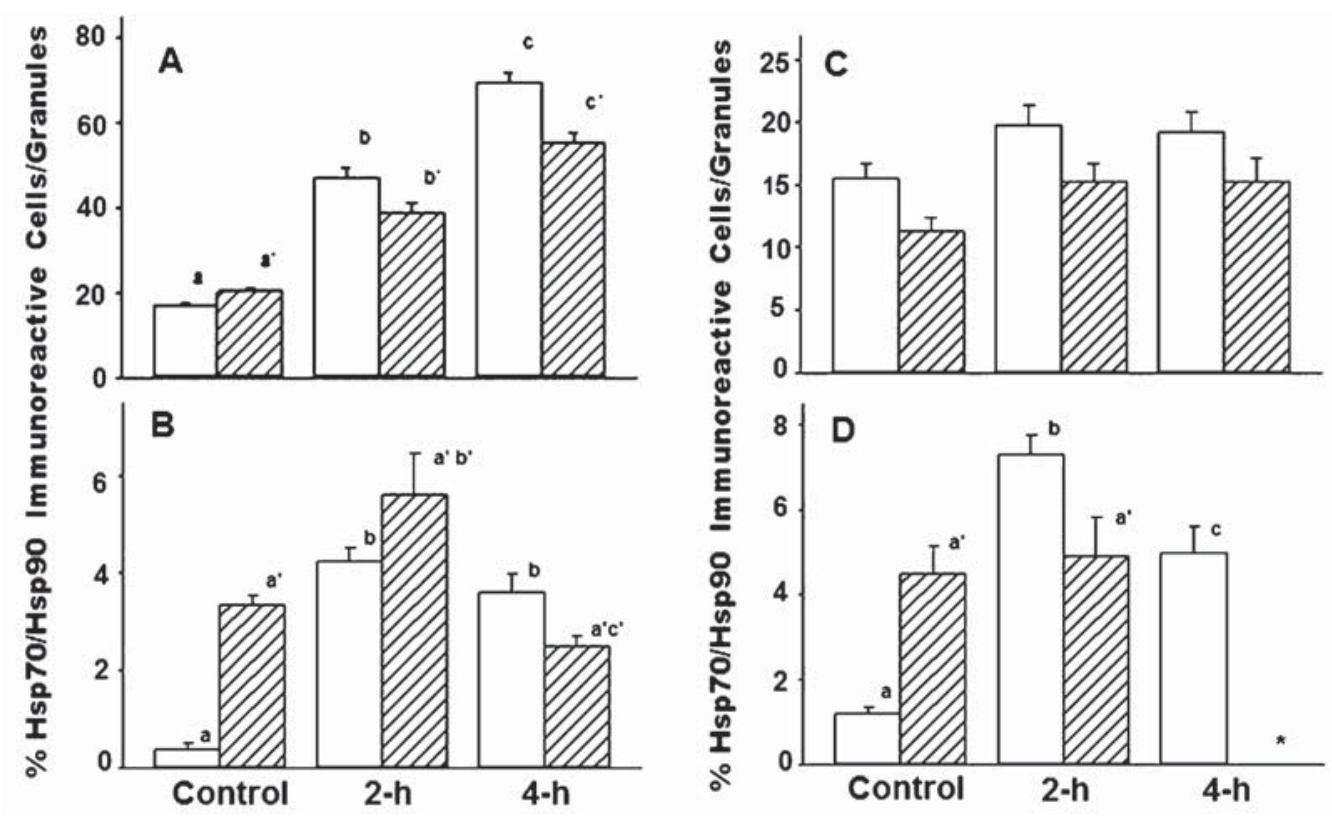

Fig. 8. Percentage (means \pm SEM) of Hsp70 (open) and Hsp90 (hatch) immunoreactive cells in epidermal tissues of Quasitetrastemma stimpsoni and Lineus alborostratus and of the granules in $100 \mu \mathrm{m}$ epidermis length ( $\mathrm{n}=5)$ in $Q$. stimpsoni and in L. alborostratus.

A - percentage of Hsp70 and Hsp90 immunoreactive cells in epidermal tissues of Q. stimpsoni; B - percentage of Hsp70 and Hsp90 immunoreactive of the granules in $100 \mu \mathrm{m}$ epidermis length in Q. stimpsoni; C - percentage of Hsp70 and Hsp90 immunoreactive cells in epidermal tissues of L. alborostratus; D - percentage of Hsp70 and Hsp90 immunoreactive of the granules in $100 \mu \mathrm{m}$ epidermis length in L. alborostratus.

Abbreviations: The asterisk indicates completely-fused granules as a continuous layer. Different a-c and a' $-\mathrm{c}$ ' represent significant differences among the Hsp70 and Hsp90 immunoreactivities, respectively.

Рис. 8. Процент (среднее \pm ошибка среднего) Hsp70 и Нsp90-иммунореактивных клеток в эпидермальных тканях Quasitetrastemma stimpsoni и Lineus alborostratus и гранул на 100 мкм эпидермиса $(\mathrm{n}=5)$ у $Q$. stimpsoni и L. alborostratus.

A - процент Hsp70 и Hsp90-иммунореактивных клеток в эпидермальных тканях Q. stimpsoni; B - процент Hsp70 и Нsp90-иммунореактивных гранул на 100 мкм эпидермиса у Q. stimpsoni; C — процент Hsp70 и Hsp90иммунореактивных клеток в эпидермальных тканях L. alborostratus; D - процент Hsp70 и Нsp90-иммунореактивных гранул на 100 мкм эпидермиса у L. alborostratus.

Обозначения: Звездочка показывает полностью слившиеся гранулы в виде непрерывного слоя. Различные а-с и a'-c' представляют существенные различия между иммунореактивностью Hsp70 и Нsp90, соответственно.

thermal stress in L. alborostratus. This response by the nemertean demonstrates the possible role of this protein as a defense mechanism against thermal stress. Hsp70 is the most prominent protein induced by elevated temperatures and plays a central role allowing cell survival during and after thermal stress (Parsell, Lindquist, 1993).

In thermally stressed Q. stimpsoni, Hsp70 and Hsp90 were barely detectable in this study. However, Hsp70 and Hsp90 immunoreactivi- ties were detected in epidermal cells and in the supra-epidermal granules. These results reveal the variability of physiological response to thermal stress as this nemertean species is abundant intertidally and often lives together with $L$. alborostratus. Both species, however, differ in body sizes ( $Q$. stimpsoni $\sim 3-5 \mathrm{~cm}$ long; $L$. alborostratus $\sim 30-40 \mathrm{~cm}$ long). Additionally, the internal morphology of the hoplonemertean Q. stimpsoni lacks the glands in subepidermal layer which consists only of extra-cellular ma- 

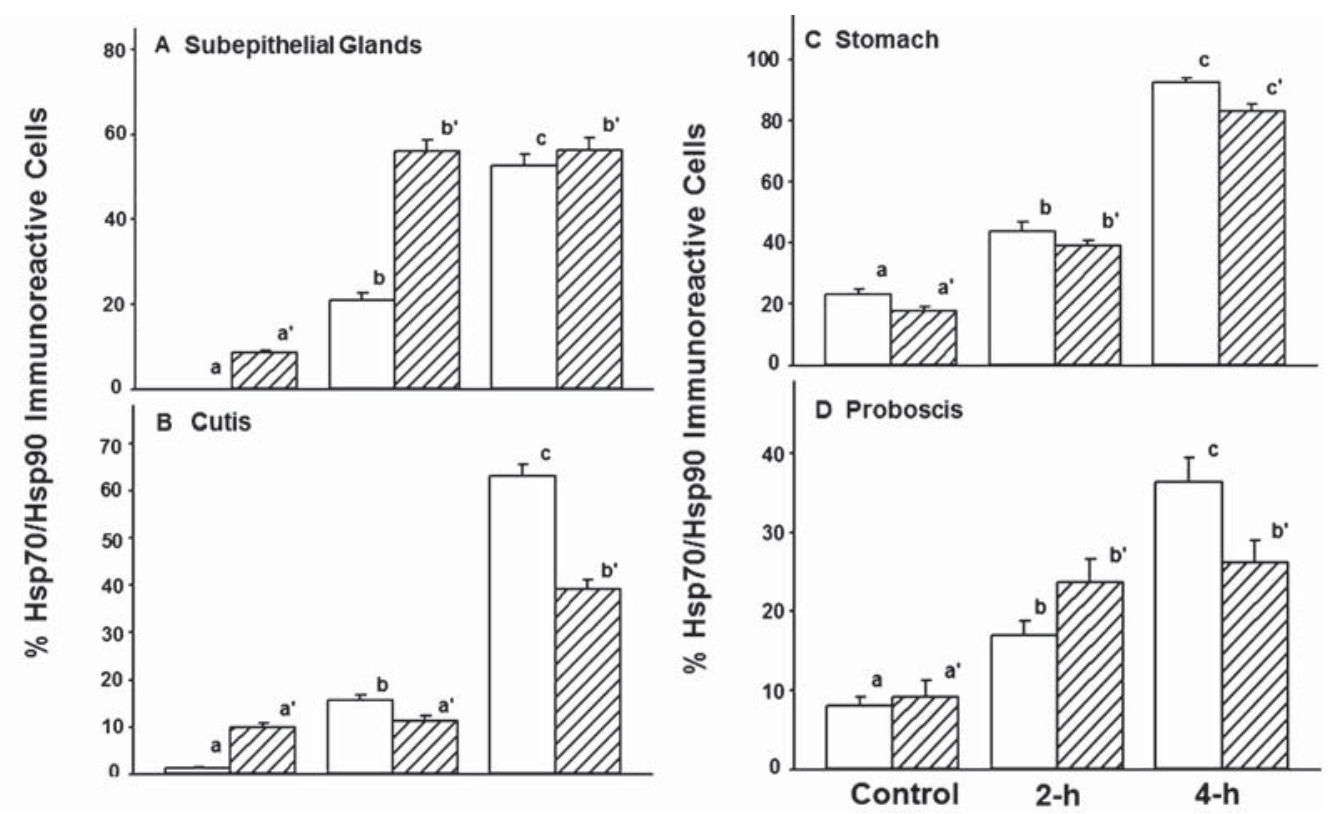

Fig. 9. Percentage (means \pm SEM) of Hsp70 (open) and Hsp90 (hatch) immunoreactive cells in the subepithelial glands, cutis, stomach and proboscis of Lineus alborostratus.

A - the subepithelial glands; B - cutis; $\mathrm{C}$ - stomach; D - proboscis.

The asterisk indicates no immunoreactivity detected in all of the samples granules as a continuous layer. Data for these four tissues for Q. stimpsoni are not shown since only few cells from the stomach and proboscis displayed Hsp90 immunoreactivity at 4-h treatment. Different a-c and a'-c' represent significant differences among the Hsp70 and Hsp90 immunoreactivities, respectively. Since some of the L. alborostratus had lost their proboscises, only five specimens were analyzed for each Hsp.

Рис. 9. Процент (среднее \pm ошибка среднего) Нsp70 и Нsp90-иммунореактивных клеток в субэпидермаальных железах, кутисе, желудке и хоботе у L. alborostratus.

А — субэпидермаальные железы; В - кутис; С - желудок; D — хобот.

Звездочка указывает на отсутствие иммунореактивности во всех образцах, где гранулы образуют непрерывный слой. Данные для этих четырех тканей у Q. stimpsoni не показаны, так как только несколько клеток в желудке и хоботе Нsp90-иммунореактивны после 4-часового теплового стресса. Различные а-с и а'-c' представляют существенные различия между Hsp70 и Hsp90-иммунореактивностью, соответственно. Так как некоторые из $L$. alborostratus потеряли свои хоботы, только пять образцов были проанализированы для каждого Нsp.

trix. However, in the heteronemertean L. alborostratus, this layer is well-developed with numerous and abundant glands which in this study showed their immunoreactivities to both Hsps. In Peter the Great Bay the reproductive season of $L$. alborostratus occurs in June with water temperatures $10-15^{\circ} \mathrm{C}$, while $Q$. stimpso$n i$ spawns in July-September with water temperatures $20-22^{\circ} \mathrm{C}$ (Chernyshev, 2014). The differences in Hsp response to thermal stress could be attributed to $Q$. stimpsoni being a more thermophilous species than L. alborostratus.

Our study showed immunoreactivities of Hsp70 and Hsp90 in both nemertean species were predominantly localized specifically in the body wall and stomach epithelia. Since nemerteans have no specialized protective structures (cuticle, exoskeleton), their body wall is the only structure that provides a barrier with respect to movement of water and solutes, as well as to environmental factors, e.g. increased temperature. In this study, differences in the distribution of Hsps were observed in the body wall. In L. alborostratus, Hsp70 and Hsp90 were detected in the epidermal cells and cutis, while in $Q$. stimpsoni these proteins were only found in the epidermal cells. Additionally, high immunoreactivities were detected in the supra- 
epidermal granules, especially after $2 \mathrm{~h}$ in both ribbon-worm species.

In this study, the two ribbon-worm species showed accumulation of Hsp immunoreactive granules on the epidermal surface. High numbers of these granules were detected for $Q$. stimpsoni at the 4-h interval while completefusion of the granules was observed for $L$. alborostratus. Interestingly, the subepidermal glands were quite active in L. alborostratus. This observation appears to demonstrate that the epidermal and subepidermal glands may be a rapid initial response to thermal stress as indicated by production of supra-epidermal granules which have fused quickly. Moreover, when irritated, Q. stimpsoni and especially $L$. alborostratus, release a large amount of mucus (A.V. Chernyshev, pers. observ.), which may play a protective role. Okazaki et al. (2001) also observed copious mucus secretion when Paranemertes peregrina were thermally stressed.

Hsps are reported to be important for the stability of the membrane lipids (Tkáèová, Angelovièová, 2012). Pratt (1997) reported that Hsp90 functions in formation of steroid receptor complexes in membranes. Presence of Hsp on cell surfaces have been observed in mammalian neurons (Sidera et al., 2004; Sidera, Patsavoudi, 2008) and in plasma membranes of tumor cells (Hantschel et al., 2000; Eustace et al., 2004; Capello et al., 2006). Interactions of Hsps with external domains of receptors and enzymes on the surfaces of tumor cells and their participation in signal transduction in various types of cells have previously been reported (Eustace et al., 2004; Sidera, Patsavoudi, 2008).

Accumulation of extracellular Hsp70 and Hsp90 on nemertean epidermal surfaces could be a part of initial intracellular responses activated by environmental stressors, such as hyperthermia. Perhaps the low Hsp concentrations detected in the immunoblots for Q. stimpsoni could be attributed to these proteins being extruded outside of the ribbon worms during its response to thermal stress. These Hsps could have been contained in the mucus or even lost to the surrounding water.
Thus, the role of Hsps in membrane viability and stability could be triggering mucus secretion which might be an important mechanism in invertebrates without protective coverings.

Therefore, these Hsps in soft-bodied nemerteans may have evolved in this spiralian taxon as a protective mechanism commonly shared from phylogenetically distant groups, e.g. bacteria, plants to mammals.

Another effective barrier in nemerteans might be the wall of their digestive system. This study showed increased Hsp70 and Hsp90 immunoreactivities in the stomach epithelium in thermally-stressed nemertean species. Similar results have been reported for vertebrates (Lalles, David, 2011). In the control L. alborostratus, Hsp90 immunoreactivity was observed in a small number of epithelial cells of the stomach but substantially increased under 2- and 4-h thermal stress. In Q. stimpsoni, Hsp90 immunoreactivity were detected in the epithelial cells and the lumen of the stomach and intestine only after 4$\mathrm{h}$ thermal stress. Moreover, in L. alborostratus exposed to maximum 4-h thermal stress, Hsp70 accumulated in the stomach. Increased concentrations of Hsp70 have been reported to protect epithelial cells of mammalian digestive tracts against toxins and ulcerogenic agents under thermal stress (Watanabe et al., 2004; Oyake et al., 2006; Pierzchalski et al., 2006; Poltronieri et al., 2008; Zhong et al., 2010). A few studies have shown that Hsp can be released from various types of cells of both vertebrates (Hightower, Guidon, 1989) and invertebrates (Tytell et al., 1986) into the extracellular matrix. The protective mechanism involving extracellular Hsp in invertebrates has not been previously studied. In mammals, extracellular Hsp has been reported to interact with the neighboring cells and protect them from death (Houenou et al., 1996).

All nemerteans characteristically possess an eversible proboscis lined by a glandular epithelium. For the control L. alborostratus, Hsp70 and Hsp90 immunoreactivities were observed in a small number of epithelial cells of the proboscis but increased substantially during subsequent exposure to thermal stress. In the 
proboscis of Q. stimpsoni, Hsp70 immunoreactivity was absent, but isolated cells with Hsp90 immunoreactivity was only detected after 4-h thermal stress. These differences could be the result of variable feeding behaviors exhibited by L. alborostratus and Q. stimpsoni. The nemertean proboscis is principally used in prey capture. In all heteronemerteans (e.g. L. alborostratus), the everted proboscis coils around the prey with its epithelium in close contact with prey tissue. In the hoplonemerteans (e.g. $Q$. stimpsoni), the proboscis possesses a terminal stylet to pierce the prey with its epithelium infrequently used in prey capture. Thus Hsps in the proboscis of L. alborostratus may be more numerous and sensitive to activation in responding to stresses in dealing with the resistance of its prey. Moreover, some of nemerteans exposed to longer duration of thermal stress lost their proboscis during the experiment.

In this study Hsp70 and Hsp90 were detected in the tissues of two different nemertean species under thermal stress. However pathological changes in nemertean tissues were not observed. These two Hsps appeared to be involved in maintaining and protecting the integrity of cellular and physiological functions. Although we only investigated Hsp70 and Hsp90, future studies could determine if other Hsps, e.g. Hsp40, Hsp60, and Hsp110 are also involved in modulating the Hsp70 and Hsp90 thermal stress responses. The role of Hsps has evolved in this group of soft bodied ribbon worms in their adaptation to a whole range of adverse environmental factors, including thermal stress.

\section{Acknowledgments}

Material collection and fixation were carried out with financial support of the Grant of Russian Science Foundation (project No 14-5000034). We thank three anonymous reviewers for their constructive comments which greatly improved the manuscript.

\section{References}

Ackerman P.A., Forsyth R.B., Mazur C.F., Iwama G.K. 2000. Stress hormones and the cellular stress response in salmonids // Fish Physiol. Biochem. Vol.23. P.327336.

Afanasyev A.A., Kotsyuba A.E., Chertok B.M. 2002. The system Allegro-MC for automatic analysis of images of micro- and macrostructures // Tikhookeansky Meditsinsky Zhurnal (Pacific Medicine Journal). Vol.3. P.65-68 [in Russian].

Arrigo A.P. 2000. sHsp as novel regulators of programmed cell death and tumorigenicity // Pathol. Bio. Vol.48. P.280-288.

Bao E.D., Sultan K.R., Nowak B., Hartung J. 2008. Localization of heat shock proteins and histopathological changes in the kidneys of transported pigs // Livest Sci. Vol.118. P.231-237.

Bierkens J.G. 2000. Applications and pitfalls of stressproteins in biomonitoring // Toxicology. Vol.153. P.61-72.

Borkan S.C., Gullans S.R. 2002. Molecular chaperones in the kidney // Ann. Rev. Physiol. Vol.64. P.503-527.

Capello F., David S., Ardizzone N., Rappa F., Marasà L., Buchieri F., Zummo G. 2006. Expression of heat shock proteins HSP10, HSP27, HSP60, HSP70, and HSP90 in urothelial carcinoma of urinary bladder // J. Cancer Mol. Vol.2. P.73-77.

Chang J., Knowlton A.A., Wasser J.S. 2000. Expression of heat shock proteins in turtle and mammal hearts: relationship to anoxia tolerance // Am. J. Physiol. Regul. Integr. Comp. Physiol. Vol.278. P.209-214.

Chen H.Y., Cheng Y.S., Shih H.H. 2015. Expression patterns and structural modelling of Hsp70 and Hsp90 in a fish-borne zoonotic nematode Anisakis pegreffii // Vet. Parasitol. Vol.212. No.3-4. P.281-291.

Chernyshev A.V. 2014. Nemertean biodiversity in the Sea of Japan and adjacent areas // S. Sun et al. (eds.). Marine Biodiversity and Ecosystem Dynamics of the North-Western Pacific Ocean. Beijing: Publishing House of Science. P.119-135.

Chernyshev A.V., Kotsyuba E. 2014. [Cystathionine $\beta$ synthase and cystathionine $\gamma$-lyase in tissues of the nemertean Cerebratulus marginatus Renier, 1804 (Nemertea)] // Russ. J. Mar. Biol. Vol.40. P.53-58 [in Russian, with English summary].

Choi Y.K., Jo P.G., Choi C.Y. 2008. Cadmium affects the expression of heat shock protein 90 and metallothionein mRNA in the Pacific oyster, Crassostrea gigas // Comp. Biochem. Physiol. C. Toxicol. Pharmacol. Vol.147. P.286-292.

Clegg J.S., Uhlinger K.R., Jackson S.A., Cherr G.N., Rifkin E., Friedman C.S. 1998. Induced thermotolerance and the heat shock protein-70 family in the Pacific oyster Crassostrea gigas // Mol. Mar. Biol. Biotech. Vol.7. P.21-30.

Eustace B.K., Sakurai T., Stewart J.K., Yimlamai D., Unger C., Zehetmeier C., Lain B., Torella C., Henning S.W., Beste G., Scroggins B.T., Neckers L., Ilag L.L., Jay D.G. 2004. Functional proteomic screens reveal an essential extracellular role for hsp90 alpha in cancer cell invasiveness // Nat. Cell. Biol. Vol.6. P.507-514.

Evgen'ev M.B., Garbuz D.G., Shilova V.Y., Zatsepina O.G. 2007. Molecular mechanisms underlying ther- 
mal adaptation of xeric animals // J. Biosci. Vol.32. P.489-499.

Fast N.M., Xue L., Bingham S., Keeling P.J. 2002. Reexamining alveolate evolution using multiple protein molecular phylogenies // J. Eukaryot. Microbiol. Vol.49. P.30-37.

Feder M.E., Hofmann G.E. 1999. Heat-shock proteins molecular chaperones, and the stress response: evolutionary and ecological physiology // Annu. Rev. Physiol. Vol.61. P.243-282.

Glover J. R., Lindquist S. 1998. Hsp104, Hsp70, and Hsp40: a novel chaperone system that rescues previously aggregated proteins // Cell. Vol.94. P.73-82.

Hamdoun A.M., Cheney D.P., Cherr G.N. 2003. Phenotypic plasticity of Hsp70 and Hsp70 gene expression in the Pacific oyster (Crassostrea gigas): implications for thermal limits and induction of thermal tolerance // Biol. Bull. Vol.205. P.160-169.

Hantschel M., Pfister K., Jordan A., Scholz R., Andeersen R., Schmitz G., Schmertzer H., Hiddemann W., Multhoff G. 2000. Hsp70 plasma membrane expression on primary tumor biopsy material and bone marrow of leukemic patients // Cell Stress Chaperones. Vol.5. P.438-442.

Hightower L.E., Guidon P.T., Jr. 1989. Selective release from cultured mammalian cells of heat shock (stress) proteins that resemble glia-axon transfer proteins // J. Cell Physiol. Vol.138. P.257-266.

Hochachka P.W., Somero G.N. 2002. Biochemical adaptation: mechanism and process in physiological evolution. / P.W. Hochachka, G.N. Somero (eds.). New York: Oxford University Press. 480 p.

Hofmann G.E., Somero G.N. 1996. Interspecific variation in thermal denaturation of proteins in the congeneric mussels Mytilus trossulus and Mytilus galloprovincialis: evidence from the heat-shock response and protein ubiquitination // Mar. Biol. Vol.126. P.65-75.

Houenou L.J., Li L., Lei M., Kent C.R., Tytell M. 1996. Exogenous heat shock cognate protein Hsc 70 prevents axotomy-induced death of spinal sensory neurons // Cell Stress Chaperones. Vol.1. P.161-166.

Huang S.Y., Tam M.F., Hsu Y.T., Lin J.H., Chen H.H., Chuang C.K., Chen M.Y., King Y.T., Lee W.C. 2005. Developmental changes of heat shock proteins in porcine testis by a proteomic analysis // Theriogenology. Vol.64. P.1940-1955.

Hunt C., Morimoto R.I. 1985. Conserved features of eukaryotic exogenous heat shock cognate protein Hsc 70 prevents axotomy-induced death of spinal sensory neurons // Proc. Natl. Acad. Sci. USA. Vol.82. No.19. P.6455-6459.

Lalles J.P., David J.C. 2011. Fasting and refeeding modulate the expression of stress proteins along the gastrointestinal tract of weaned pigs // J. Anim. Physiol. Anim. Nutr. Vol.95. P.478-488.

Liang S., Yu X., Wood D.E., Jolly E.R. 2013. Hsp70 and Hsp90 are differentially expressed in crayfish muscle and neurons after heat stress // Research and Reports in Biology. Vol.4. P.41-50.
Lilja K., Prevodnik A., Gardeström J., Elfwing T., Tedengren M., Bollner T. 2008. Regional differences in mRNA responses in blue mussels within the Baltic proper// Comp. Biochem. Physiol. C. Vol.148. P.101106.

Lindquist, S. 1986. The heat-shock response // Annu. Rev. Biochem. Vol. 55. P. 1151-1191.

Lindquist S., Craig E.A. 1988. The heat-shock proteins // Annu. Rev. Genet. Vol.22. P.631-677.

Lowry O.H., Rosenbrough N.J., Farr A.L., Randall R.J. 1951. Protein measurement with the Folin phenol reagent // J. Biol. Chem. Vol.193. P.265-275.

Mager W.H., de Boer A.H., Siderius M.H., Voss H.P. 2000. Cellular responses to oxidative and osmotic stress // Cell Stress Chaperones. Vol.5. P.73-75.

Maloyan A., Palmon A., Horwitz M. 1999. Heat acclimation increase the basal HSP72 level and alters its production dynamics during heat stress // Am. J. Physiol. Regul. Integr. Comp. Physiol. Vol.276. P.1505-1515.

Mayer M.P., Bukau B. 2005. Hsp70 chaperones: cellular functions and molecular mechanism // Cell. Mol. Life Sci. Vol.62. P.670-684.

Monribot-Villanueva J., Juárez-Uribe R.A., PalomeraSánchez Z., Gutiérrez-Aguiar L., Zurita M., Kennison J.A., Vázquez M. 2013. TnaA, an SP-RING protein, interacts with Osa, a subunit of the chromatin remodeling complex BRAHMA and with the SUMOylation pathway in Drosophila melanogaster // PLoS ONE. Vol.8. No.4. doi: 10.1371/journal.pone.0062251.

Mario L.C., Borghesi J., Crivellari-Damasceno W.T., Favaron P.O., Carreira A.C., Will S.E., Maria D.A., Miglino M.A. 2016. Egg and fourth instar larvae gut of Aedes aegypti as a source of stem cells // Tissue Cell. Vol.48. P.558-565.

Moseley P.L. 1997. Heat shock proteins and heat adaptation of the whole organism // J. Appl. Physiol. Vol.83. P.1413-1417.

Okazaki R.K., Ye W., Berthélémy-Okazaki N.J., Chang E.S. 2001. Preliminary study of heat shock proteins in nemerteans // Hydrobiologia. Vol.456. P.211-219.

Okazaki R.K., Gillins M.A., Duerden B.J., Hodges C., Record N.R. 2006. Osmotic induction of stress proteins in nemerteans // J. Nat. Hist. Vol.40. P.10351046.

Oyake J., Otaka M., Matsuhashi T., Jin M., Odashima M., Komatsu K., Wada I., Horikawa Y., Ohba R., Hatakeyama N., Itoh H., Watanabe S. 2006. Over-expression of $70-\mathrm{kDa}$ heat shock protein confers protection against monochloramine-induced gastric mucosal cell injury // Life Sci. Vol.79. P.300-305.

Parsell D.A., Lindquist S. 1993. The function of heat shock proteins in stress tolerance: degradation and reactivation of damaged proteins // Ann. Rev. Gen. Vol.27. P.437-496.

Piano A., Valbonesi P., Fabbri E. 2004. Expression of cytoprotective proteins, heat shock protein 70 and metallothioneins, in tissues of Ostrea edulis exposed to heat and heavy metals // Cell Stress Chaperones. Vol.9. P.134-142. 
Pierzchalski P., Krawiec A., Ptak-Belowska A., Barañska A., Konturek S.J., Pawlik W.W. 2006. The mechanism of heat-shock protein 70 gene expression abolition in gastric epithelium caused by Helicobacter pylori infection // Helicobacter. Vol.11. P.96-104.

Poltronieri C., Negrato E., Bertotto D., Majolini D., Simontacchi C., Radaelli G. 2008. Immunohistochemical localization of constitutive and inducible heat shock protein 70 in carp (Cyprinus carpio) and trout (Oncorhynchus mykiss) exposed to transport stress // Eur. J. Histochem. Vol.52. P.191-198.

Prahlad V., Cornelius T., Morimoto R.I. 2008. Regulation of the cellular heat shock response in Caenorhabditis elegans by thermosensory neurons // Science. Vol.320. P.811-814.

Pratt W.B. 1997. The role of the hsp90-based chaperone system in signal transduction by nuclear receptors and receptor signaling via map kinase // Ann. Rev. Pharmacol. Toxicol. Vol.37. P.297-326.

Pratt W.B., Toft D.O. 2003. Regulation of signaling protein function and trafficking by the Hsp90/Hsp70based chaperone machinery//Exp. Biol. Med. Vol.228. No.2. P.111-133.

Pruski A.M., Dixon D.R. 2007. Heat shock protein expression pattern (Hsp70) in the hydrothermal vent mussel Bathymodiolus azoricus // Mar. Environ. Res. Vol.64. P.209-224.

Richter K., Haslbeck M., Buchner J. 2010. The heat shock response: life on the verge of death // Mol. Cell. Vol.40. No.2. P.253-266.

Sanders B.M. 1993. Stress proteins in aquatic organisms: an environmental perspective // Crit. Rev. Toxicol. Vol.23. P.49-75.

Sanders B.M., Hope C., Pascoe V.M., Martin L.S. 1991. Characterization of the stress protein response in two species of Collisella limpets with different temperature tolerances // Physiol. Zool. Vol.64. P.1471-1489.

Sidera K., Patsavoudi E. 2008. Extracellular HSP90: conquering the cell surface // Cell Cycle. Vol.7. P.15641568 .

Sidera K., Samiotaki M., Yfanti E., Panayotou G. Patsavoudi E. 2004. Involvement of cell surface HSP90 in cell migration reveals a novel role in the developing nervous system // J. Biol. Chem. Vol.279. P.4537945388.

Sokal R.R., Rohlf F.J. 1994. Biometry: the principles and practices of statistics in biological research. $3^{\text {rd }}$ ed. San Francisco, CA: WH Freeman. 880 p.

Sørensen J.G., Dahlgaard J., Loeschcke V. 2001. Genetic variation in thermal tolerance among natural populations of Drosophila buzzatii: down regulation of Hsp70 expression and variation in heat stress resistance traits // Funct. Ecol. Vol.15. P.289-296.
Sørensen J.G., Norry F.M., Scannapieco A.C., Loeschcke V. 2005. Altitudinal variation for stress resistance traits and thermal adaptation in adult Drosophila buzzatii from the New World // J. Evol. Biol. Vol.18. P.829-837.

Spees J.L., Chang S.A., Snyder M.J., Chang E.S. 2002. Thermal acclimation and stress in the American lobster, Homarus americanus: equivalent temperature shifts elicit unique gene expression patterns for molecular chaperones and polyubiquitin // Cell Stress Chaperones. Vol.7. P.97-106.

Tirard C.T., Grossfeld R.M., Levine J.F., Kennedy-Stoskopf S. 1997. Effect of osmotic shock on protein synthesis of oyster hemocytes in vitro // Comp. Biochem. Physiol. A. Vol.116. P.43-49.

Tomanek L., Somero G.N. 1999. Evolutionary and acclimation-induced variation in the heat shock responses of congeneric marine snails (genus Tegula) from different thermal habitats: Implication for limits of thermotolerance and biogeography // J. Exp. Biol. Vol.202. P.2925-2936.

Tomanek L., Somero G.N. 2000. Time course and magnitude of synthesis of heat-shock proteins in congeneric marine snails (genus Tegula) from different tidal heights // Physiol. Biochem. Zool. Vol.73. P.249256.

Tkáčová J., Angelovičová M. 2012. Heat shock proteins (HSPs): a review // Anim. Sci. Biotech. Vol.45. P.349353.

Tytell M., Greenberg S.G., Lasek R.G. 1986. Heat shocklike protein is transferred from glia to axon // Brain Res. Vol.363. P.161-164.

Watanabe D., Otaka M., Mikami K., Yoneyama K., Goto T., Miura K., Ohshima S., Lin J.G., Shibuya T., Segawa D., Kataoka E., Konishi N., Odashima M., Sugawara M., Watanabe S. 2004. Expression of a 72$\mathrm{kDa}$ heat shock protein, and its cytoprotective function, in gastric mucosa in cirrhotic rats // J. Gastroenterol. Vol.39. P.724-733.

Young J.C., Agashe V.R., Siegers K., Hartl F.U. 2004. Pathways of chaperone-mediated protein folding in the cytosol // Nat. Rev. Mol. Cell Biol. Vol.5. P.781791.

Zhang W., Zhu Y.H., Yang J.C., Yang G.Y., Zhou D., Wang J.F. 2015. A selected Lactobacillus rhamnosus srain promotes EGFR-independent Akt activation in an enterotoxigenic Escherichia coli K88-infected IPEC-J2 cell model // PLoS ONE. 10:e125717.

Zhong X., Wang T., Zhang X., Li W. 2010. Heat shock protein 70 is upregulated in the intestine of intrauterine growth retardation piglets // Cell Stress Chaperones. Vol.15. P.335-342.

Responsible editor E.N. Temereva 